Jurnal Artikel

\title{
Perbaikan Tata Letak Gudang dengan Metode Dedicated Storage dan Class Based Storage serta Optimasi Alokasi Pekerjaan Material Handling di PT. Dua Kuda Indonesia
}

\author{
Helena Sitorus $^{1}$, Rudianto ${ }^{2}$, Meriastuti Ginting ${ }^{3}$ \\ ${ }^{12}$ Program Studi Teknik Industri, Fakultas Teknik, Univeritas Bhayangkara Jakarta Raya \\ ${ }^{1}$ helena.sitorus@dsn.ubharajaya.ac.id, ${ }^{2}$ rudiannt84@gmail.com, ${ }^{2}$ meriastuti.ginting@ukrida.ac.id \\ *Corresponding author - Email : meriastuti.ginting@ukrida.ac.id
}

Artkel Info - : Received : 8 Aug 2020; Revised : 28 Aug 2020; Accepted: 31 Aug 2020

\begin{abstract}
Tingkat pelayanan gudang barang jadi PT. Dua Kuda Indonesia masih kurang 1,7\% dalam memenuhi permintaan barang. Penempatan barang di gudang tidak beraturan, bercampur, dan berdasarkan space kosong yang tersedia. Alokasi beban kerja yang berbiaya minimum untuk kedua forklift sebagai alat material handling belum diperhitungkan. Untuk itu dilakukan penelitian yang bertujuan menentukan tata letak yang menghasilkan total jarak perpindahan terkecil dan optimasi alokasi beban kerja forklift. Perbandingan metode Dedicated Storage dan Class Based Storage dilakukan untuk memilih layout dengan jarak tempuh terkecil. Metode Transportasi digunakan dalam menentukan optimasi alokasi pekerjaan forklift. Hasil penelitian menunjukkan bahwa layout terpilih adalah layout dengan metode Class Based Storage. Dibandingkan layout awal, layout ini memberikan penurunan jarak perpindaham sebesar 32,24\% dan peningkatan produktivitas sebesar 49,98\%. Alokasi pekerjaan yang optimum yaitu forklit 3 ton mengambil dan menyimpan barang di blok $A, B$ (23 slot), $E, F$ dan forklift 2,5 ton di blok $B$ ( 1 slot), $C, D, G$ dan $H$.
\end{abstract}

Kata kunci: tata letak, Dedicated Storage, Class Based Storage, transportasi

\section{Abstract}

The level of finish good warehouse service at PT. Dua Kuda Indonesia still lack $1.7 \%$ in meeting the demand for goods. Placement of goods in warehouses is irregular, mixed, and based on available empty space. The allocation of a minimum cost of workload for both forklifts as a material handling tool has not been taken into account. For this reason, research is aimed at determining the layout that produces the smallest total displacement distance and optimizing the forklift workload allocation. A comparison of Dedicated Storage and Class Based Storage methods is done to choose the layout with the smallest distance traveled. The transportation method is used in determining the optimization of forklift work allocation. The results showed that the selected layout was a Class Based Storage method. Compared to the initial layout, this layout gives a reduction in the distance of the move by $32.24 \%$ and an increase in productivity by 49.98\%. The optimum work allocation is a 3-ton forklift taking and storing goods in blocks A, B (23 slots), $E, F$ and 2.5 tons forklifts in block $B$ (1 slot), $C, D, G$ and $H$.

Keywords: layout, Dedicated Storage, Class Based Storage, transportation

\section{PENDAHULUAN}

Tata letak fasilitas merupakan masalah yang penting dalam sistem manufaktur modern saat ini. Kondisi lahan yang semakin terbatas mengakibatkan perusahaan-perusahaan yang ada semakin terdorong untuk mengupayakan sistem penyimpanan (gudang) yang lebih terpadu (Zaerpour \& de Koster, 2017). Disamping 
itu salah satu upaya yang dapat dilakukan untuk meningkatkan daya saing adalah dengan pengelolaan gudang dengan baik, khususnya gudang finished goods (Hidayat \& Maarif, 2018). Penelitian yang menyatakan bahwa sekitar $23 \%$ biaya logistik di US dan 39\% di Eropa terletak pada aktivitas di gudang mengakibatkan mengelola gudang dengan cara hemat biaya menjadi perhatian perusahaan yang ingin mengurangi pengaruh biaya yang cukup signifikan ini (Fumi, Scarabotti, \& Schiraldi, 2013). Inilah yang menjadi dasar pentingnya penelitian perencanaan ulang tata letak gudang.

Tata letak gudang menyangkut pengaturan ruang penyimpanan dan material handling yang ditujukan untuk memaksimumkan utilitas ruang, efisiensi, menurunkan biaya, dan peningkatan produktivitas dengan meminimalkan jarak tempuh untuk menyimpan (storage) dan mengambil (order picking) sebuah item barang. Hal ini akan dipengaruhi oleh dimensi gudang, panjang lorong (pick aisle dan cross aisle), metode pengambilan, sistem material handling, dan infrastruktur teknologi informasi pendukung.

Tata letak gudang yang baik berarti mengatur peralatan dalam suatu fasilitas sedemikian rupa sehingga membantu fasilitas tersebut bekerja secara produktif karena memberikan kemudahan dalam operasional dan kecepatan pelayanan, terhindar dari pekerjaan yang bolak-balik karena peralatan/barang sudah ditempatkan sesuai dengan karakteristiknya. Skema tata letak yang baik akan memberikan kontribusi pada efisiensi operasi secara keseluruhan (Zhenyuan, Xiaohong, Wei, Jie, \& Wang, 2011).

Gudang PT. Dua Kuda menyimpan barang jadi berupa bahan-bahan kimia. Saat ini permintaan pengeluaran barang tidak dapat terpenuhi 100 sementara jumlah barang yang tersedia di gudang melebihi jumlah permintaan. Operator gudang sering mengalami kesulitan dalam mengambil dan menyimpan barang karena barang disimpan tak beraturan dan bercampur. Barang disimpan pada space kosong yang tersedia tanpa memperhatikan apakah barang di sekitarnya adalah barang yang sama atau tidak. Area gudang digunakan seluruhnya tanpa memperhitungkan penggunaan area penyimpanan yang tepat. Demikian juga lebar lorong belum diperhitungkan seefisien mungkin. Terdapat 2 forklift yang digunakan untuk alat material handling yaitu forklift 3 ton dan 2,5 ton. Kedua forklift digunakan secara acak padahal keduanya mengkonsumsi bahan bakar yang berbeda. Forklift 3 ton mengkonsumsi bahan bakar 2,1 liter/jam dan forklift 2 liter/jam. Apabila secara acak forklift 3 ton selalu mengangkut barang ke area penyimpanan yang terjauh tentu saja biaya akan tinggi. Biaya perpindahan material perlu diminimumkan dengan mengalokasikan beban kerja pada masing-masing forklift.

Untuk mengatasi permasalahan tersebut di atas, maka penelitian ini bertujuan untuk menentukan tata letak yang menghasilkan total jarak perpindahan minimum dan menentukan alokasi optimum beban kerja masing-masing forklift.

\section{METODE PENELITIAN}

Beberapa penelitian terdahulu tentang perencanaan ulang tata letak fasilitas telah memberikan hasil penurunan jarak tempuh dan penurunan biaya material handling serta meningkatkan efisiensi dengan berbagai metode. Dua diantaranya adalah Dedicated Storage (Astuti, Pratikto, Irawan, \& Sugiono, 2016), (Febianti, Ilhami, \& G., 2016; 1(2)), (Meldra \& Purba, 2018), (Audrey, Sukania, \& Nasution, 2019) dan Class Based Storage (Basuki \& Kudori, 2016) (Hidayat \& Maarif, 2018) (Johan \& Suhada, 2018). Penelitian-penelitian yang tersebut di atas menyatakan bahwa metode yang digunakan telah berhasil menurunkan jarak perpindahan, menurunkan biaya material 
handing termasuk penambahan allowance area penyimpanan.

Penelitian ini akan melakukan perencanaan ulang tata letak fasilitas dengan membandingkan metode Dedicated Storage dan Class Based Storage serta dan memilih metode yang memberikan jarak perpindahan dan biaya material handling paling minimum. Sedangkan untuk mengoptimasi alokasi beban forklift akan menggunakan metode transportasi dengan metode Vogel Approximation Method (VAM) solusi layak dasar dan Stepping Stone untuk mendapatkan solusi optimal.

\subsection{Dedicated Storage}

Dedicated Storage adalah metode yang sering disebut sebagai penyimpanan yang sudah tertentu dan tetap karena lokasi untuk tiap barang sudah ditentukan tempatnya (Tompkins \& Bozer, 2010). Kebijakan demikian didesain dengan luas penyimpanan setiap item sama dengan level maksimal persediaan.

Langkah-langkah pembuatan tata letak dengan Dedicated Storage adalah:

1. Menghitung Space Requirement :

$$
S_{j}=\frac{\text { Penyimpanan maksimum }}{\text { ukuran kapasitas blok }}
$$

2. Menghitung Throughput (Aktivitas Penyimpanan) :

$$
T_{j}=\left(\frac{\text { Rata-rata penerimaan }}{\text { jumlah Pemindahan Sekali Angkut }}\right)+
$$

3. Penempatan produk pada lokasi penyimpanan dilakukan dengan menghitung $T_{j} / S_{j}$. Penempatan dimulai dengan nilai perbandingan $T_{j} / S_{j}$ terbesar di area terdekat ke titik in out (I/O) berturut-turut hingga nilai perbandingan $\mathrm{T}_{\mathrm{j}} / \mathrm{S}_{\mathrm{j}}$ terkecil di area terjauh.

\subsection{Class Based Storage}

Class Based Storage merupakan metode penyimpanan barang dengan membagi item-item ke dalam kelas-kelas berdasarkan kesamaan kriteria tertentu seperti jenis material, tipe movement (fast moving, medium moving, slow mowing) dan lainnya. Heragu (2006) mengelompokkan material dalam gudang menjadi tiga kelas yaitu kelas A, kelas B, dan kelas $\mathrm{C}$ berdasarakan pada hukum pareto dengan pertimbangan pada aktivitas level storage dan retrieval (S/R) pada aktivitas dalam gudang. Pengaturan tempat dirancang lebih fleksibel karena tiap kelas ditempatkan pada daerah tertentu dan masing-masing kelas dapat disusun secara acak.

\subsection{Metode Rectilinier Distance}

Jarak perjalanan (distance traveled) merupakan jarak yang harus ditempuh material handling dari lokasi penyimpanan ke titik in/out (I/O) sebagai titik awal perjalanan. Metode rectilinier distance mengukur jarak sepanjang lintasan dengan menggunakan garis tegak lurus (orthogonal) satu dengan yang lainnya. Pengukurannya dilakukan dengan rumus berikut:

$d_{i j}=\left|X_{i}-X_{j}\right|+\left|Y_{i}-Y_{j}\right|$

\subsection{Metode Transportasi}

Ongkos material handling sebanding dengan jarak perpindahan barang saat keluar dan masuk Gudang. Biaya ini perlu diminimumkan karena merupakan bagian dari biaya di gudang. Alokasi optimum pekerjaan alat material handling dalam memasukkan dan mengeluarkan barang di gudang perlu dilakukan supaya mendapatkan biaya yang minimum. Dalam hal ini metode yang digunakan adalah metode Transportasi. Metode ini menentukan pekerjaan apa saja yang dialokasikan pada tiap alat material handling berikut jumlah pekerjaannya sehingga total biaya perpindahan barang minimum.

Model transportasi adalah model pemindahan penumpang atau barang dari satu tempat ke tempat lain. Sesuai dengan namanya, model ini berkaitan dengan 
penentuan rencana biaya terendah untuk mengirim sesuatu dari sejumlah sumber ke sejumlah tujuan (Taha, 2007). Solusi optimum persoalan transportasi diperoleh dengan terlebih dahulu mendapatkan solusi layak dasar dan dilanjutkan dengan mencari solusi optimum. Solusi layak dasar yang digunakan adalah Vogel Approximation Method (VAM). Metode lanjutan untuk mendapatkan solusi optimal adalah metode Stepping Stone dan U-V Multiplier Modified Distribution Method (MODI

\section{TAHAPAN PENELITIAN}

Secara lebih lengkap tahapan penelitian diuraikan seperti berikut ini.

a. Pengumpulan data (rata-rata jumlah barang masuk, keluar dan yang disimpan setiap hari

b. Menghitung kebutuhan ruang (space requirement) dan aktivitas (throughput)

c. Mengggambarkan layout awal dan menghitung jarak perpindahan

d. Relayout menggunakan metode Dedicated Storage

- Menghitung nilai throughput/space requirement (T/S) dan mengurutkan nilai $\mathrm{T} / \mathrm{S}$ dari terbesar sampai terkecil

- Penempatan area penyimpanan item berdasatkan nilai T/S tertinggi sampai terendah berturut-turut sebagai area terdekat sampai terjauh dari in/out (pintu gudang)

- Menggambar layout metode Dedicated Storage

- Menghitung jarak perpindahan layout metode Dedicated Storage

e. Relayout menggunakan metode Dedicated Storage

- Mengelompokkan item-item berdasarkan nilai throughput ke dalam kelas A (tinggi), B(sedang), dan $\mathrm{C}$ (rendah)

- Penempatan area penyimpanan berdasarkan kelas berturut-turut dari kelas A,B,C sebagai area terdekat sampai terjauh dari in/out (pintu gudang).

- Menggambar layout metode Classed Based Storage

- Menghitung jarak perpindahan layout metode Classed Based Storage

f. Pemilihan layout terbaik (yang menghasilkan jarak perpindahan terpendek) dengan cara membandingkan nilai jarak perpindahan metode Dedicated Storage dengan metode Classed Based Storage

g. Membandingkan layout terpilih dengan layout awal

h. Melakukan optimasi alokasi beban Forklift dengan VAM dan Stepping Stone.

\section{JASIL DAN PEMBAHASAN \\ 4.1 Pengumpulan Data}

Data yang diketahui dari gudang finished goods PT. Dua Kuda Indonesia diantaranya adalah luas gudang $=3750 \mathrm{~m}^{2}$, panjang $=75 \mathrm{~m}$, lebar $=50 \mathrm{~m}$. Jumlah slot $=220$ slot , panjang slot $=4,6 \mathrm{~m}$, lebar slot $=1,5 \mathrm{~m}$ dengan kapasitas slot $=8$ palet dengan susunan 4 palet di bawah dan 4 palet disusun diatasnya. Ukuran palet penyimpanan adalah $110 \times 150 \times 15(\mathrm{~cm})$ dengan kapasitas 1 ton. Space palet adalah $115 \times 150 \times 15$ dimana ada tambahan untuk panjang $5 \mathrm{~cm}$ dan lebar $20 \mathrm{~cm}$. Alat material handling adalah forklift 3 ton dan 2,5 ton dengan jumlah operator $=6$ orang. Sedangkan data penyimpanan dan keluar masuk barang di gudang untuk periode tahun 2019 dapat dilihat pada tabel 1.

\subsection{Pengolahan Data}

Perhitungan Kebutuhan Ruang dan Throughput (Aktivitas)

Menggunakan Pers.1 dan Pers. 2 dapat dihitung kebutuhan ruang dan throughput. Sebagai contoh perhitungan dapat dilihat untuk produk Stearic Acid 1860 sebagai berikut: 
Tabel 1. Penyimpanan, Pemasukan, dan engeluaran Harian Barang di Gudang

\begin{tabular}{|c|c|c|c|c|c|c|c|}
\hline \multirow{2}{*}{ No } & \multirow{2}{*}{ Nama Item } & \multicolumn{2}{|c|}{$\begin{array}{c}\text { Penyimpanan } \\
\text { Maksimum }\end{array}$} & \multicolumn{2}{|c|}{ Rata-rata Penerimaan } & \multicolumn{2}{|c|}{$\begin{array}{c}\text { Rata-rata } \\
\text { Pemgambilan }\end{array}$} \\
\hline & & $\begin{array}{c}\text { Jumlah } \\
\text { (ton) }\end{array}$ & Palet & $\begin{array}{c}\text { Jumlah } \\
\text { (ton) }\end{array}$ & Palet & $\begin{array}{c}\text { Jumlah } \\
\text { (ton) }\end{array}$ & Palet \\
\hline 1 & $\begin{array}{l}\text { Stearid } \\
\text { Acid } 1680\end{array}$ & 38,59 & 39 & 13,55 & 14 & 13,14 & 14 \\
\hline 2 & $\begin{array}{l}\text { Stearid } \\
\text { Acid } 1820\end{array}$ & 125,23 & 126 & 37,38 & 38 & 34,52 & 35 \\
\hline 3 & $\begin{array}{l}\text { Stearid } \\
\text { Acid } 1838\end{array}$ & 374,78 & 375 & 130,17 & 131 & 128,76 & 129 \\
\hline 4 & $\begin{array}{l}\text { Stearid } \\
\text { Acid } 1842\end{array}$ & 297,17 & 298 & 153,67 & 154 & 151,73 & 152 \\
\hline 5 & $\begin{array}{l}\text { Stearid } \\
\text { Acid } 1850\end{array}$ & 23,09 & 24 & 6,56 & 7 & 6,56 & 7 \\
\hline 6 & $\begin{array}{l}\text { Stearid } \\
\text { Acid } 1685\end{array}$ & 18,95 & 19 & 4,78 & 5 & 4,19 & 5 \\
\hline 7 & $\begin{array}{l}\text { Stearid } \\
\text { Acid } 1832\end{array}$ & 30,52 & 31 & 4,64 & 5 & 4,64 & 5 \\
\hline 8 & $\begin{array}{l}\text { Stearid } \\
\text { Acid } 1860\end{array}$ & 144,24 & 145 & 48,87 & 49 & 46,95 & 47 \\
\hline 9 & Glycerine & 107,92 & 108 & 51,1 & 52 & 47,94 & 48 \\
\hline 10 & Acid Oil & 19,58 & 20 & 7,81 & 8 & 7,68 & 8 \\
\hline 11 & $\mathrm{AW}$ & 70,06 & 71 & 31,91 & 32 & 31,18 & 32 \\
\hline \multirow[t]{2}{*}{12} & HRBDPS & 225,15 & 226 & 103,8 & 104 & 100,67 & 101 \\
\hline & Total & $1.475,28$ & 1.482 & 594,24 & 599 & 577,96 & 583 \\
\hline
\end{tabular}

Kebutuhan Luas Lantai $=5 \times 4,6 \mathrm{~m} \times 1,5 \mathrm{~m}$ $=34,5 \mathrm{~m}^{2}$

Throughput (aktivitas) penerimaan atau pengiriman pada gudang finished goods menggunakan forklift sebagai material handling. Dalam sekali pengangkutan forklift dapat mengangkat sebanyak 1 ton (1 palet) untuk semua jenis barang. Sebagai contoh perhitungan dapat dilihat untuk produk Stearic Acid 1860 sebagai berikut: $\mathrm{T}=\frac{14}{1}+\frac{14}{1}=28$

Dengan cara yang sama untuk produk lain diperoleh kebutuhan ruang dan throughput untuk semua item di gudang seperti pada tabel 2.

Tabel 2. Space Requirement (Kebutuhan Ruang)

\begin{tabular}{|c|c|c|c|c|c|c|c|}
\hline \multirow{2}{*}{ No } & \multirow{2}{*}{ Nama Item } & \multirow{2}{*}{$\begin{array}{l}\text { Penyimpa } \\
\text { nan } \\
\text { Maksimu } \\
\text { m (ton) }\end{array}$} & \multirow{2}{*}{$\begin{array}{c}\text { Space } \\
\text { Requirem } \\
\text { ent (slot) }\end{array}$} & \multirow{2}{*}{$\begin{array}{c}\text { Kebutuhan } \\
\text { Luas Area } \\
\left(\mathrm{m}^{2}\right)\end{array}$} & \multirow{2}{*}{$\begin{array}{c}\text { Throughp } \\
\text { ut } \\
\text { /Aktivitas } \\
\text { (palet) }\end{array}$} & \multicolumn{2}{|c|}{$\begin{array}{c}\text { Rata-rata } \\
\text { Pemgambilan }\end{array}$} \\
\hline & & & & & & $\begin{array}{l}\text { Jumlah } \\
\text { (ton) }\end{array}$ & Palet \\
\hline 1 & $\begin{array}{l}\text { Stearid } \\
\text { Acid } 1680\end{array}$ & 38,59 & 5 & 34,5 & 28 & 13,14 & 14 \\
\hline 2 & $\begin{array}{l}\text { Stearid } \\
\text { Acid } 1820\end{array}$ & 125,23 & 16 & 110,4 & 73 & 34,52 & 35 \\
\hline 3 & $\begin{array}{l}\text { Stearid } \\
\text { Acid } 1838\end{array}$ & 374,78 & 47 & 324,3 & 260 & 128,76 & 129 \\
\hline 4 & $\begin{array}{l}\text { Stearid } \\
\text { Acid } 1842\end{array}$ & 297,17 & 38 & 262,2 & 306 & 151,73 & 152 \\
\hline 5 & $\begin{array}{l}\text { Stearid } \\
\text { Acid } 1850\end{array}$ & 23,09 & 3 & 20,7 & 14 & 6,56 & 7 \\
\hline 6 & $\begin{array}{l}\text { Stearid } \\
\text { Acid } 1685\end{array}$ & 18,95 & 3 & 20,7 & 10 & 4,19 & 5 \\
\hline 7 & $\begin{array}{l}\text { Stearid } \\
\text { Acid } 1832\end{array}$ & 30,52 & 4 & 27,6 & 10 & 4,64 & 5 \\
\hline 8 & $\begin{array}{l}\text { Stearid } \\
\text { Acid } 1860\end{array}$ & 144,24 & 19 & 131,1 & 96 & 46,95 & 47 \\
\hline 9 & Glycerine & 107,92 & 14 & 96,6 & 100 & 47,94 & 48 \\
\hline 10 & Acid Oil & 19,58 & 3 & 20,7 & 16 & 7,68 & 8 \\
\hline 11 & AW & 70,06 & 9 & 62,1 & 64 & 31,18 & 32 \\
\hline 12 & HRBDPS & 225,15 & 29 & 200,1 & 205 & 100,67 & 101 \\
\hline & Total & $1.475,28$ & 190 & $1.311,00$ & 1.182 & 577,96 & 583 \\
\hline
\end{tabular}

\section{Tata Letak Awal}

Jumlah slot pada tata letak sekarang berjumlah 220 slot. Barang-barang ditempatkan pada space kosong yang tersedia. Pada tata letak gudang awal lebar gang belum mempunyai ukuran yang baku. Perusahaan hanya menentukan jumlah slot untuk masing-masing baris. Tata letak awal gudang PT. Dua Kuda Indonesia dapat dilihat pada gambar 1.

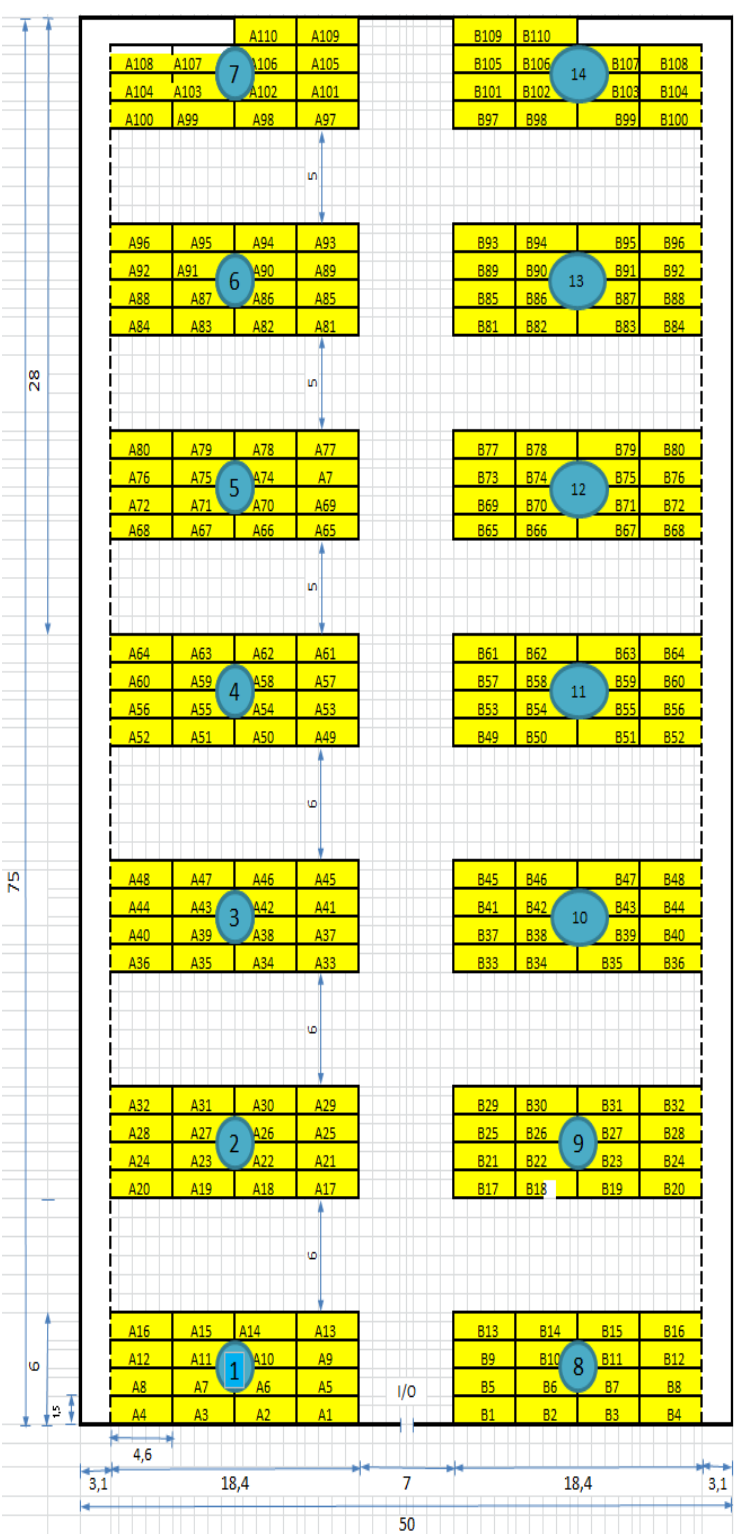

Gambar 1. Tata Letak PT. Dua Kuda Indonesia

Ukuran kotak persegi 1x1 menunjukkan ukuran sebenarmya $1 \mathrm{~m} x$ 1m. Jarak tiap blok ke titik in/out (I/O atau titik awal keluar masuk) dihitung dengan metode rectilinier. Berikut adalah contoh perhitungan untuk blok 1 berdasarkan 
gambar 1 . Dengan $\mathrm{i}=$ blok 1 dan $\mathrm{j}=\mathrm{I} / \mathrm{O}$ yaitu pintu gudang yang merupakan titik awal yaitu titik $(0,0)$ berada pada pojok kiri bawah.

$\mathrm{Xi}=3,1+(18,4 / 2)=12,3$ dan $\mathrm{Yi}=6 / 2=3$

$\mathrm{Xj}=3,1+18,4+(7 / 2)=25$ dan $\mathrm{Yj}_{=} 0$

$\mathrm{d}_{\mathrm{ij}}=|\mathrm{Xi}-\mathrm{Xj}|+|\mathrm{Yi}-\mathrm{Yj}|=12,3-25$ $|+| 3-0 \mid=15,7$

Total barang keluar dan masuk $=599+$ $583=1182$ palet $=147,75$ slot $(1$ slot $=8$ palet)

Frekuensi keluar masuk tiap blok = $147,75 / 14=10,55$

Total jarak tempuh dari blok $1=\mathrm{d}_{\mathrm{ij}} \mathrm{x}$ Frekuensi $=15,7 \times 10,55=165,69 \mathrm{~m}$

Demikian selanjutnya dengan cara yang sama dilakukan perhitungan untuk blok 2 - 14 sehingga diperoleh hasil seperti pada tabel 3 .

Tabel 3. Perhitungan Jarak Tempuh Tata Letak Gudang Awal

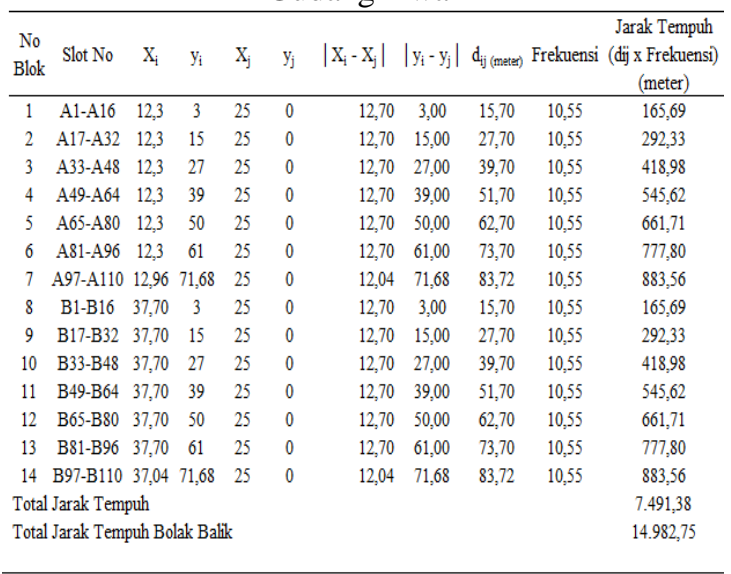

Gambar 1 dan Tabel 3 menunjukkan bahwa luas lantai terpakai untuk penyimpanan $=(75 \times 50)-((3,1 \times 75 \times 2)+$ $(4,6 \times 1,5 \times 2))=3257,4 \mathrm{~m}^{2}$. Kapasitas gudang $=220+4=224$ slot. Rata-rata jarak tempuh tiap slot $=14.982,75 / 190=$ $78,86 \mathrm{~m}$. Fleksibilitas $=((224-190) / 190) \mathrm{x}$ $100 \%=17,89 \%$. Jumlah slot $/ \mathrm{m}^{2}=$ $190 / 3257,4=0,06$. Produktivitas $=190 / 6$ $=31,67$ slot per operator.

\section{Tata Letak dengan Metode Dedicated Storage}

Langkah-langkah dalam penempatan produk:
1. Perankingan produk berdasarkan perbandingan Throughput $(\mathrm{Tj})$ dan Storage $(\mathrm{Sj})$ seperti pers. 3. Sebagai contoh perhitungan untuk produk Stearic Acid 1680 adalah: $\frac{T}{S}=\frac{28}{5}: 5,6$ Aktivitas. Untuk perbandingan Throughput (Tj) dan Storage $(\mathrm{Sj})$ item barang berdasarkan urutan ranking selanjutnya dapat dilihat pada tabel 4 berikut:

Tabel 4. Perbandingan Throughput (Tj) dan Storage $(\mathrm{Sj})$

\begin{tabular}{|c|c|c|c|c|c|}
\hline No & Nama Item & $\begin{array}{c}\text { Throughput } \\
\text { (Aktivitas) }\end{array}$ & $\begin{array}{c}\text { Space } \\
\text { Requirement } \\
\text { (slot) }\end{array}$ & $\begin{array}{c}\text { T/S } \\
\text { (Aktivitas/ } \\
\text { Slot) }\end{array}$ & $\begin{array}{c}\text { Warna di } \\
\text { Tata Letak }\end{array}$ \\
\hline 1 & Stearid Acid & 306 & 38 & 8,05 & \\
\hline 2 & Glycerine & 100 & 14 & 7,14 & \\
\hline 3 & $\mathrm{AW}$ & 64 & 9 & 7,11 & \\
\hline 4 & HRBDPS & 205 & 29 & 7,07 & \\
\hline 5 & Stearid Acid & 28 & 5 & 5,6 & 17 \\
\hline 6 & Stearid Acid & 260 & 47 & 5,53 & \\
\hline 7 & Acid Oil & 16 & 3 & 5,33 & \\
\hline 8 & Stearid Acid & 96 & 19 & 5,05 & \\
\hline 9 & Stearid Acid & 14 & 3 & 4,67 & \\
\hline 10 & Stearid Acid & 73 & 16 & 4,56 & \\
\hline 11 & Stearid Acid & 10 & 3 & 3,33 & \\
\hline \multirow[t]{2}{*}{12} & Stearid Acid & 10 & 4 & 2,5 & \\
\hline & Total & 1182 & 190 & & \\
\hline
\end{tabular}

2. Penempatan dan Perhitungan Jarak

Perhitungan daerah jalur forklift dihitung dengan memperkirakan panjang diagonal forklift. Karena panjang diagonal forklift 3 ton lebih besar dari forklift 2,5 ton maka yang akan digunakan sebagai pertimbangan untuk menetapkan lebar gang pada gudang finished goods adalah panjang diagonal forklift 3 ton.

Panjang diagonal forklift 3 ton $=$

$$
\sqrt{(3,78)^{2}+(1,23)^{2}}=3,98=4 \mathrm{~m}
$$

Item dengan ranking $\mathrm{T} / \mathrm{S}$ tertinggi ditempatkan di area terdekat ke pintu keluar masuk sebagai titik awal (I/O). Urutan ranking pertama adalah Stearid Acid 1842 yang membutuhkan area sebanyak 38 slot. Item ini ditempatkan di 38 area slot terdekat ke titik I/O. Slot-slot yang didedikasikan ke Stearid Acid 1842 adalah slot A001 - A019 dan slot B001 B019. Urutan penempatan selanjutnya adalah Glycerine karena item ini adalah ranking ke dua. Item ranking pertama dan ranking ke dua diberi jarak sejauh $4 \mathrm{~m}$. Jarak ini adalah space kosong untuk jalur 
material handling dengan menggunakan forklift berdiagonal $4 \mathrm{~m}$. Glycerine membutuhkan area sebanyak 14 slot yaitu pada slot A020-A026 dan B020-B026. Demikian selanjutnya penempatan setiap item berturut-turut di area terdekat sampai terjauh dari $\mathrm{I} / \mathrm{O}$ berdasarkan prioritas urutan ranking T/S. Penempatan keseluruhan item dapat dilihat pada gambar 2 berikut:

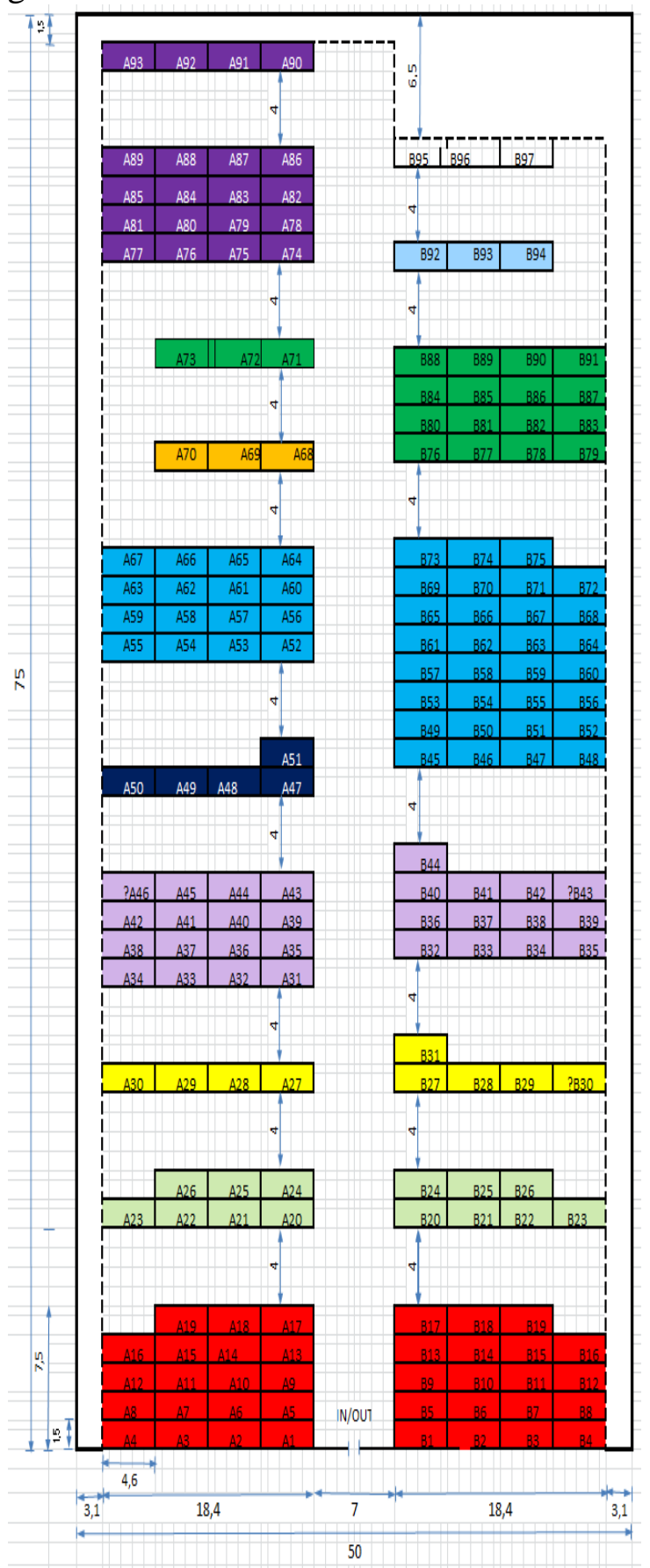

Gambar 2. Tata Letak Dedicated Storage
Jarak tiap slot ke titik in/out (I/O atau titik awal keluar masuk) dihitung dengan metode rectilinier.

Tabel 5. Perhitungan Jarak Tempuh Tata Letak Dedicated Storage

\begin{tabular}{|c|c|c|c|c|c|c|c|c|c|c|c|}
\hline \begin{tabular}{l|l}
$\mathrm{No}$ & Nama Item
\end{tabular} & $\begin{array}{l}\text { Slot } \\
\text { No }\end{array}$ & $\mathrm{Xi}$ & ji 1. & $\mathrm{Xj}_{\mathrm{X}} \mathrm{y}$ & $\mathrm{yj}$ & $\left|X_{i}-X_{j}\right|$ & $|y-y-y|$ & $\operatorname{dj}(\mathrm{m})$ & Frekluensi & \begin{tabular}{|c|} 
Jarak Temphih \\
(dij X Frehiensisi) \\
(m)
\end{tabular} & \begin{tabular}{|c|} 
Jarak \\
Tempuh \\
$\operatorname{Item}(\mathrm{m})$
\end{tabular} \\
\hline 1 Stearid Acid 1842 & Al & 19 & 0,8 & 25 & 0 & 5.8 & 0,75 & 6,55 & 1,007 & 6.59 & \multirow{4}{*}{$609: 28$} \\
\hline 2 StearidAcid 1842 & A2 & 15 & 0,8 & 25 & 0 & 10,4 & 0,75 & 11,15 & 1,007 & 11,22 & \\
\hline & & & & & & : & & & & & \\
\hline 38 Steanid Acid 1842 & B19 & 40 & 6.8. & 25 & 0 & 15 & 6.75 & 21.75 & 1,007 & 2189 & \\
\hline 39 Gilycerine & A20 & 19 & 12 & 25 & 0 & 5,8 & 12,25 & 18,05 & 0,893 & 16,12 & \multirow{4}{*}{307,59} \\
\hline 40 Glycerine & A21 & 15 & 12 & 25 & 0 & 10,4 & 12,25 & 22.65 & 0,893 & 20,22 & \\
\hline & & & & & & 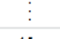 & & & ( & & \\
\hline 52 Glyceme & B26 & 40 & 14 & 25 & 0 & 15 & 13,75 & 28.75 & 0.893 & 25.67 & \\
\hline $53 \mathrm{AW}$ & A27 & 19 & 19 & 25 & 0 & 5,8 & 19,25 & 25,05 & 0,889 & 22.27 & \multirow{4}{*}{250,80} \\
\hline 54 |aW & A28 & 15 & 19 & 25 & 0 & 10,4 & 19,25 & 29.65 & 0,889 & 26,36 & \\
\hline & & $\vdots$ & $\vdots$ & $\vdots$ & 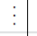 & & & $\vdots$ & $\vdots$ & $\vdots$ & \\
\hline $61 \mathrm{AW}$ & B31 & 31 & 21 & 25 & 0 & 58 & 20,75 & 2655 & 0.889 & 2360 & \\
\hline 62. HRBDPS & A31 & 19 & 25 & 25 & 0 & 5,8 & 24,75 & 30.55 & 0.884 & 26,99 & \multirow{3}{*}{$1.022,48$} \\
\hline 63 HRBDPS & A32 & 15 & 25 & 25 & 0 & 10,4 & 24,75 & 35,15 & 0.884 & 31,06 & \\
\hline 90 IRBDPS & B44 & 31 & 31 & 25 & 0 & 5.8 & 30,75 & 3655 & 0.884 & 3230 & \\
\hline 91 Stearid Acid 1680 & A47 & 19 & 35 & 25 & 0 & 5,8 & 34,75 & 40,55 & 0,700 & 28,39 & \multirow{4}{*}{162,30} \\
\hline 92 Stenid Acid 1680 & A48 & 15 & 35 & 25 & 0 & 10,4 & 34,71 & 45,15 & 0,700 & 31,61 & \\
\hline & & $\vdots$ & $\vdots$ & r. & & : & & $\vdots$ & $\vdots$ & $\vdots$ & \\
\hline 95 StearidAcid 1680 & A51 & 19 & 36 & 25 & 0 & 5,8 & 36.25 & 42.05 & 0,700 & 29,44 & \\
\hline 96 SteanidAcid 1838 & A52 & 19 & 42 & 25 & 0 & 5,8 & 41,75 & 47,55 & 0,691 & 3288 & \multirow{4}{*}{$1.780,76$} \\
\hline 97 StearidAcid 1838 & A53 & 15 & 42 & 25 & 0 & 10,4 & 41,75 & 52,15 & 0,691 & 36,06 & \\
\hline & & & $\vdots$ & $\vdots$ & & & & $\vdots$ & & & \\
\hline 142 Stearid Acid 1838 & B75 & 40 & 47 & 25 & 0 & 15 & 46,75 & 61,75 & 0,691 & 42,70 & \\
\hline 143 Acid Oil & A68 & 19 & 52 & 25 & 0 & 5,8 & 51,75 & 57,55 & 0,667 & 38,37 & \multirow{3}{*}{124,30} \\
\hline 144 Acid Oil & A69 & 15 & 52 & 25 & 0 & 10,4 & 51,75 & 62.15 & 0,667 & 41,43 & \\
\hline 145. $\mathrm{Acd}$ OH & A70 & 10 & 52 & 25 & 0 & 15 & 51,71 & 66,75 & 0,667 & 44,50 & \\
\hline 146 StenidAcid 1860 & A71 & 19 & 57 ? & 25 & 0 & 5,8 & 57,25 & 63,05 & 0,632 & 39,82 & \multirow{4}{*}{807,25} \\
\hline 147 Stearid Acid 1860 & A72 & 15 & 572 & 25 & 0 & 10,4 & 57,25 & 67,65 & 0,632 & 42,73 & \\
\hline & & & & & & & & & & & \\
\hline 164|SteanidAcid 1860 & B91 & 45 & 57 & 25 & 0 & 19,6 & 36,75 & 76.35 & 0,632 & 48,22 & \\
\hline $165 \mid$ Stearid Acid 1850 & B92 & 31 & $62 \mid$ & 25 & 0 & 5,8 & 62,25 & 68.05 & 0.583 & 39,70 & \multirow{3}{*}{127,14} \\
\hline 166| Steanid Acid 1850 & B93 & 35 & 62 & 25 & 0 & 10,4 & 62,25 & 72.65 & 0,583 & 42,38 & \\
\hline 167 Stearid Acid 1850 & B94 & 40 & 62 & 25 & 0 & 15 & 62,25 & 77.25 & 0,583 & 45,06 & \\
\hline $168 \mid$ Stearid Acid 1820 & A74 & 19 & 63 & 25 & 0 & 5.8 & 62,75 & 68.55 & 0,570 & 39,09 & \multirow{4}{*}{ 709,01 } \\
\hline $169 \mid$ Steanid Acid 1820 & A75 & 15 & 63 & 25 & 0 & 10,4 & 62,75 & 73,15 & 0,570 & 41,72 & \\
\hline & & & $\vdots$ & . & & $\vdots$ & & $\vdots$ & . & & \\
\hline 1883 Stearid Acid 1820 & A89 & 5,4 & 67 & 25 & 0 & 19.6 & 67.25 & 86,85 & 0,570 & 49,53 & \\
\hline 184 Stearid Acid 1685 & B95 & 31 & 68 & 25 & 0 & 5.8 & 67,75 & 73,55 & 0,417 & 30,65 & \multirow{3}{*}{97,69} \\
\hline 185 Steanid Acid 1685 & B96 & 35 & $68: 2$ & 25 & 0 & 10,4 & 67,79 & 78,15 & 0,417 & 32,56 & \\
\hline 186| SteanidAcid 1685 & B97 & 40 & 68 & 25 & 0 & 15 & 67,75 & 82.75 & 0,417 & 34,48 & \\
\hline 187 Steanid Acid 1832 & A90 & 19 & 73 & 25 & 0 & 3,8 & 72,71 & 78,55 & 0,313 & 24,55 & \multirow{4}{*}{106,81} \\
\hline 188 Steanid Acid 1832 & A91 & 15 & 73 & 25 & 0 & 10,4 & 72,75 & 83,15 & 0,313 & 25,98 & \\
\hline 189 Stearid Acid 1832 & A92 & 10 & 73 & 25 & 0 & 15 & 72,75 & 87,75 & 0,313 & 27,42 & \\
\hline $190 \mid$ Stearid Acid 1832 & A93 & 5,4 & 73 & 25 & 0 & 19,6 & 72,75 & 92.35 & 0,313 & 28,86 & \\
\hline Total Jarak Tempunh & & & & & & & & & & & $6.105,41$ \\
\hline Total Jarak Tempun Bola & & & & & & & & & & & $122.210,82$ \\
\hline
\end{tabular}

Berikut adalah contoh perhitungan untuk slot A1 berdasarkan gambar 2 di atas: $\mathrm{i}=\operatorname{slot} \mathrm{A} 1$ dan $\mathrm{j}=\mathrm{I} / \mathrm{O}$ yaitu pintu gudang yang merupakan titik awal.

Titik $(0,0)$ berada pada pojok kiri bawah $\mathrm{Xi}=3,1+(3 \mathrm{x} 4,6)+(4,6 / 2)=19,2$ dan $\mathrm{Yi}$ $=1,5 / 2=0,75$ $\mathrm{Xj}=3,1+18,4+(7 / 2)=25$ dan $\mathrm{Yj}_{=} 0$ 
$\mathrm{d}_{\mathrm{ij}}=|\mathrm{Xi}-\mathrm{Xj}|+|\mathrm{Yi}-\mathrm{Yj}|=19,2-25$
$|+| 0,75-0 \mid=6,55$

Slot A ditempati Stearid Acid 1842 dimana jumlah keluar masuk 306 palet $=$ 38,25 slot dan ruang penyimpanannya 38 slot.

Frekuensi keluar masuk tiap slot Stearid Acid $1842=38,25 / 38=1,007$

Total jarak tempuh dari slot $\mathrm{A} 1=\mathrm{d}_{\mathrm{ij}} \mathrm{X}$ Frekuensi $=6,55 \times 1,007=6,59 \mathrm{~m}$

Demikian selanjutnya dengan cara yang sama dilakukan perhitungan untuk seluruh 190 slot sehingga diperoleh hasil seperti pada tabel 5 .

Gambar 2 dan tabel 5 di atas menunjukkan beberapa hal berikut yaitu :

- Luas lantai terpakai untuk penyimpanan $=(75 \times 50)-$ $((3,1 \times 75 \times 2)+(25,4 \times 1,5)+(18,4 \times 6,5))$ $=3.127,3 \mathrm{~m}^{2}$

- Kapasitas gudang $=190+22=212$ slot

- Rata-rata jarak tempuh tiap slot $=$ $12.210,82 / 190=64,27 \mathrm{~m}$

- Fleksibilitas $=((212-190) / 190) \mathrm{x}$ $100 \%=11,58 \%$

- Jumlah slot $/ \mathrm{m}^{2}=190 / 3.127,3=0,06$ Jumlah operator tata letak awal

Jumlah operator dedicated storage $=$ Jarak tempuh tata letak awali

Jarak tempuh dedicated storage

Jumlah operator dedicated storage $=$ $(6 \times 12.219,82) / 14,982,75=4,89=5$ orang

- Produktivitas $=190 / 5=38$ slot per operator

Tata Letak dengan Metode Class Based Storage

1. Pembentukan Kelas

Pembentukan kelas dilakukan berdasarkan throughput yang menunjukkan frekuensi keluar masuk item dari dan ke gudang. Kelas dibentuk dengan pendekatan Pareto. Berikut pada tabel 6 adalah pembentukan kelas.

2. Penempatan dan Perhitungan Jarak

Item-item di gudang ditempatkan pada blok-blok dimana jumlah blok di sisi kanan dan kiri jumlahnya sama. Jumlah slot terbanyak dari 12 item adalah Stearic
Acid 1838 yaitu sebanyak 47 slot. Item ini akan dialokasikan masing-masing ke dalam blok kiri dan kanan sebanyak 47/2= 23,5 slot. Tiap blok berisikan kolom sebanyak 4 slot sehingga untuk Stearid Acid 1838 banyaknya baris dalam satu blok adalah 23,5/4 $=5,875=6$ slot. Jadi ukuran 1 blok uuntuk Stearic Acid 1838 adalah 4 slot (kolom) x 6 slot (baris) dengan jumlah total slot 24. Ukuran blok digunakan untuk keseluruhan item di gudang. Maka jumlah blok yang diperlukan adalah 190/24 =7,92 = 8 blok yang disusun masing-masing 4 blok di sisi kiri dan 4 blok di sisi kanan. Selanjutnya diitung jarak tiap-tiap slot ke titik I/O dan menempatkan item kelas $\mathrm{A}$ di area berjarak terkecil ke I/O diikuti kelas B dan kemudian kelas $\mathrm{C}$.

Tabel 6. Hasil Pembentukan Kelas

\begin{tabular}{|c|c|c|c|c|c|c|}
\hline No Nama Item & $\begin{array}{c}\text { Throulpu } \\
t \\
\text { (Aktivitas) }\end{array}$ & $\begin{array}{c}\text { Persentase } \\
\text { Throuhput } \\
(\%)\end{array}$ & $\begin{array}{c}\text { Persentase } \\
\text { Kumulatif } \\
\text { Throughtput } \\
(\%) \\
\end{array}$ & $\begin{array}{c}\text { Kela } \\
\text { s }\end{array}$ & $\begin{array}{c}\text { Persentase } \\
\text { Jumlah } \\
\text { Item (\%) }\end{array}$ & $\begin{array}{c}\text { Persentase } \\
\text { Nilai (\%) }\end{array}$ \\
\hline 1 Stearid Acid & 306 & 26 & 26 & & & \\
\hline 2 Stearid Acid & 260 & 22 & 48 & A & 25 & 65 \\
\hline 3 HRBDPS & 205 & 17 & 65 & & & \\
\hline 4 Glycerine & 100 & 8 & 74 & & & \\
\hline 5 Stearid Acid & 96 & 8 & 82 & $B$ & 33 & 28 \\
\hline 6 Stearid Acid & 73 & 6 & 88 & B & & 28 \\
\hline $7 \mathrm{AW}$ & 64 & 5 & 93 & & & \\
\hline 8 Stearid Acid & 28 & 2 & 96 & & & \\
\hline 9 Acid 0il & 16 & 1 & 97 & & & \\
\hline 10 Stearid Acid & 14 & 1 & 98 & C & 42 & 7 \\
\hline 11 Stearid Acid & 10 & 1 & 99 & & & \\
\hline 12 Stearid Acid & 10 & 1 & 100 & & & \\
\hline Total & 1182 & 100 & & & 100 & 100 \\
\hline
\end{tabular}

Alokasi item menunjukkan bahwa satu jenis item yang sama posisinya berjauhan. Hal ini dapat menimbulkan kesalahan pengambilan dan atau penyimpanan. Untuk itu dilakukan penyesuaian alokasi item dengan menempatkan satu jenis item yang sama pada satu lokasi atau berdekatan dengan tetap mengacu pada penenmpatan item yang memiliki throughput tinggi pada lokasi dengan jarak terkecil ke in/out. Hasil penyesuaiannya dapat dilihat pada gambar 3 


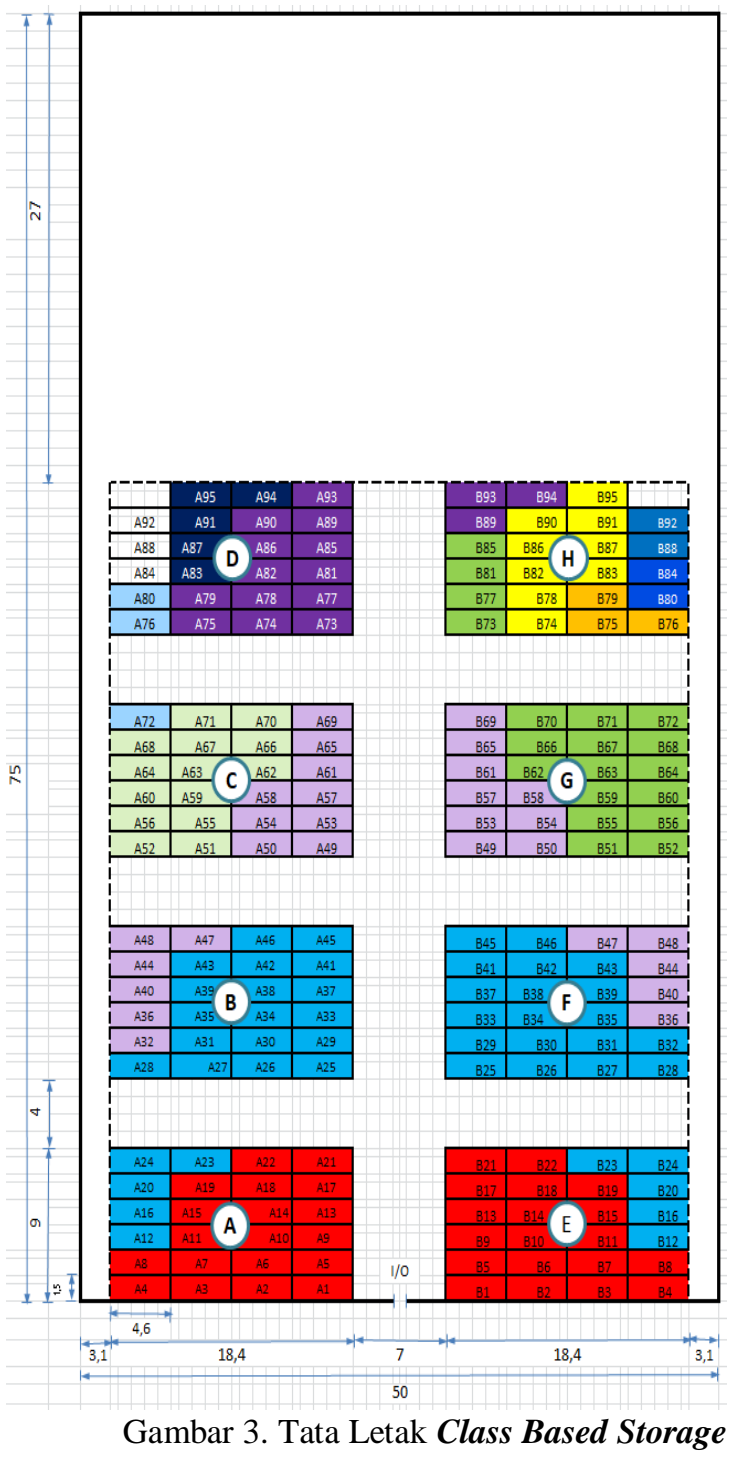

Berikut pada tabel 7 adalah kelas item dan space requirement :

Tabel 7. Kelas Item dan Storage Requirement

\begin{tabular}{|c|c|c|c|c|}
\hline No & Kelas & Nama Item & Warna & $\begin{array}{c}\text { Space Requirement } \\
\text { (slot) }\end{array}$ \\
\hline 1 & \multirow{3}{*}{ A } & Stearid Acid 1842 & & 38 \\
\hline 2 & & Stearid Acid 1838 & & 47 \\
\hline 3 & & HRBDPS & & 29 \\
\hline 4 & \multirow{4}{*}{ B } & Glycerine & & 14 \\
\hline 5 & & Stearid Acid 1860 & & 19 \\
\hline 6 & & Stearid Acid 1820 & & 16 \\
\hline 7 & & AW & & 9 \\
\hline 8 & \multirow{5}{*}{$\mathrm{C}$} & Stearid Acid 1680 & & 5 \\
\hline 9 & & Acid Oil & & 3 \\
\hline 10 & & Stearid Acid $\mathbf{1 8 5 0}$ & & 3 \\
\hline 11 & & Stearid Acid 1832 & & 4 \\
\hline 12 & & Stearid Acid 1685 & & 3 \\
\hline & & Total & & 190 \\
\hline
\end{tabular}

Jarak tiap slot ke titik in/out (I/O atau titik awal keluar masuk) dihitung dengan metode rectilinier. Berikut adalah contoh perhitungan untuk slot A1 berdasarkan gambar 3 di atas : $\mathrm{i}=\operatorname{slot} \mathrm{A} 1$ dan $\mathrm{j}=\mathrm{I} / \mathrm{O}$ yaitu pintu gudang yang merupakan titik awal.

Titik $(0,0)$ berada pada pojok kiri bawah

$\mathrm{Xi}=3,1+(3 \times 4,6)+(4,6 / 2)=19,2$ dan $\mathrm{Yi}$

$=1,5 / 2=0,75$

$\mathrm{Xj}=3,1+18,4+(7 / 2)=25$ dan $\mathrm{Yj}_{=} 0$

$\mathrm{d}_{\mathrm{ij}}=|\mathrm{Xi}-\mathrm{Xj}|+|\mathrm{Yi}-\mathrm{Yj}|=19,2-25$

$|+| 0,75-0 \mid=6,55$

Slot A ditempati Stearid Acid 1842 dimana jumlah keluar masuk 306 palet $=$ 38,25 slot dan ruang penyimpanannya 38 slot.

Frekuensi keluar masuk tiap slot Stearid Acid $1842=38,25 / 38=1,007$

Total jarak tempuh dari slot $\mathrm{A} 1=\mathrm{d}_{\mathrm{ij}} \mathrm{x}$ Frekuensi $=6,55 \times 1,007=6,59 \mathrm{~m}$

Demikian selanjutnya dengan cara yang sama dilakukan perhitungan untuk seluruh 190 slot sehingga diperoleh hasil seperti pada tabel 8 berikut :

Tabel 8. Perhitungan Jarak Tempuh Tata Letak Class Based Storage

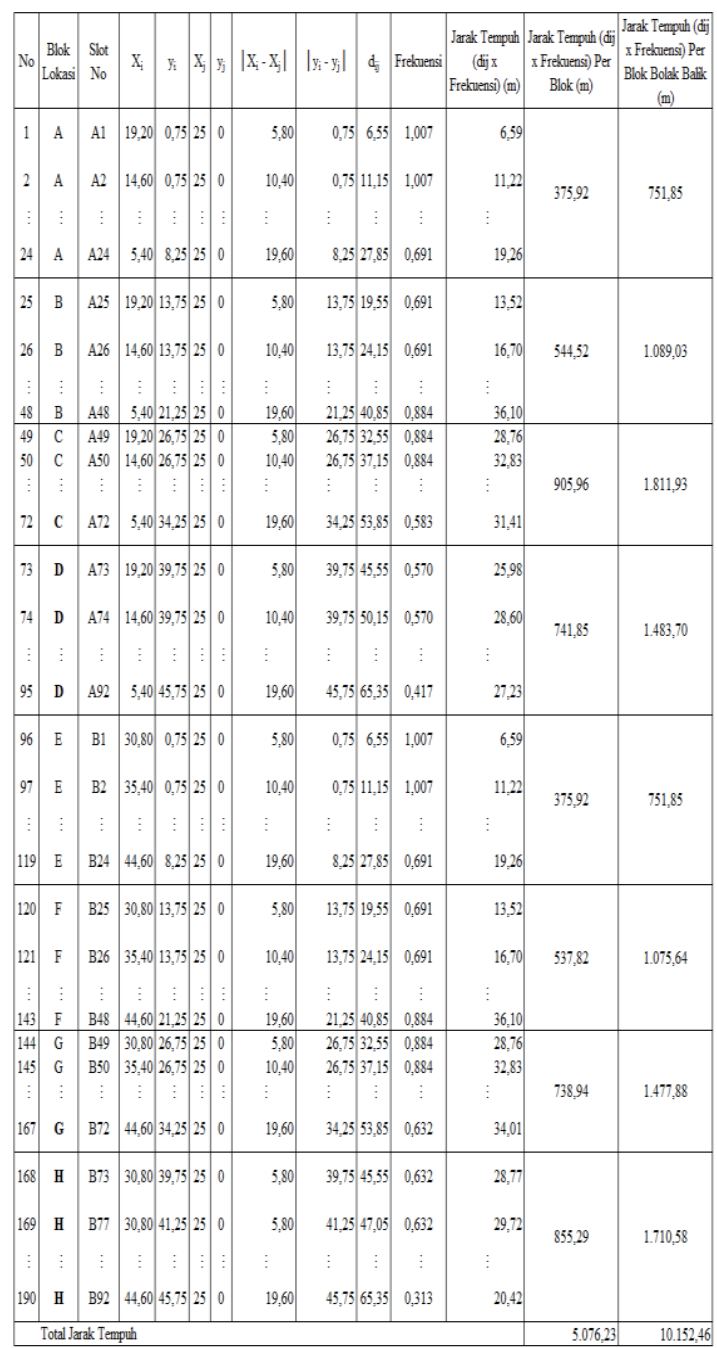


Gambar 3 dan tabel 8 di atas menunjukkan beberapa hal berikut yaitu :

- Luas lantai terpakai untuk penyimpanan $=(75 \times 50)-((3,1 \times 75 \times 2)+(43,8 \times 27)=$ $2.102,4 \mathrm{~m}^{2}$

- Kapasitas gudang $=190+(24 \times 4)+2=$ 288 slot

- Rata-rata jarak tempuh tiap slot $=$ $10.152,46 / 190=53,43 \mathrm{~m}$

- Fleksibilitas $=((288-190) / 190) \times 100 \%$ $=51,58 \%$

- Jumlah slot $/ \mathrm{m}^{2}=190 / 2.102,4=0,09$

- $\frac{\text { Jumlah operator tata letak awal }}{\text { Jumlah operator class based storage }}=$ Jarak tempuh tata letak awali Jarak tempuh class based storage

Jumlah operator class based storage $=$ $(6 \times 10.152,46) / 14,982,75=4$ orang

- Produktivitas $=190 / 4=47,5$ slot per operator

Perbandingan 3 jenis tata letak gudang menunjukkan bahwa tata letak terpilih adalah tata letak gudang class based storage. Jika dibandingkan dengan tata letak awal maka tata letak ini memberikan perbandingan pada table 9 berikut.

Tabel 9. Perbandingan 3 Jenis Tata Letak Gudang

\begin{tabular}{|c|c|c|c|c|}
\hline Deskripsi & Tata Letak Awal & $\begin{array}{c}\text { Tata Letak } \\
\text { Dedicated } \\
\text { Storage }\end{array}$ & $\begin{array}{c}\text { Tata Letak } \\
\text { Class Based } \\
\text { Storage }\end{array}$ & $\begin{array}{c}\text { Perbandingan } \\
\text { (Naik/Turun) } \\
\%\end{array}$ \\
\hline Jarak Tempuh (m) & $14.982,75$ & $12.219,82$ & $10.152,46$ & 32,24 \\
\hline $\begin{array}{l}\text { Luas Lantai Terpakai untuk } \\
\text { Penyimpanan }\left(\mathbf{m}^{2}\right)\end{array}$ & $3.257,40$ & $3.127,00$ & $2.102,40$ & 35,46 \\
\hline Kapasitas Gudang (slot) & 224 & 212 & 288 & 28,57 \\
\hline $\begin{array}{l}\text { Rata-rata Jarak Tempuh Tiap } \\
\text { Slot(m) }\end{array}$ & 78,86 & 64,27 & 53,43 & 32,25 \\
\hline Fleksibilitas (\%) & 17,89 & 11,58 & 51,58 & 188,32 \\
\hline Jumlah Slotm² ${ }^{2}$ & 0,06 & 0,06 & 0,09 & 50 \\
\hline Jumlah Operator (orang) & 6 & 5 & 4 & 33,33 \\
\hline Produktivitas (slotoperator') & 31,67 & 38 & 47,5 & 49,98 \\
\hline
\end{tabular}

\section{Optimasi Alokasi Beban Forklift denganMetode Transportasi}

Material handling di gudang dilakukan dengan menggunakan forklift 3 ton dan 2,5 ton. Metode transportasi digunakan untuk mendapatkan total biaya transportasi yang minimum dengan mengalokasikan beban kerja yang tepat untuk tiap forklift. Perhitungan biaya transportasi forklift 3 ton ke blok A untuk tata letak gudang class based storage dapat dilihat sebagai berikut berikut :

- Jarak tempuh blok A (lihat tabel 9) = $751,85 \mathrm{~m}=0,75185 \mathrm{~km}$

- Waktu tempuh blok A dimana kecepatan rata-rata forklift $4 \mathrm{~km} / \mathrm{jam}=0,75185 / 4=$ 0,19 jam

- Konsumsi solar blok A dimana per jam 2,1 liter $=0,19 \times 2,1=0,39$ liter

- Konsumsi solar per slot di blok A dimana blok $\mathrm{A}$ ada 24 slot $=0,39 / 24=0,02$ liter

- Biaya transportasi per slot di blok A dimana harga solar Rp 9.600,- per liter $=$ $0,02 \times 9600=\operatorname{Rp} 157.89$,-

Demikian selanjutnya dilakukan dengan cara yang sama untuk perhitungan biaya seluruh blok dengan forklift 3 ton dan 2,5 ton sehimgga diperoleh hasil seperti pada tabel 10 dan 11 berikut:

Tabel 10. Biaya Transportasi per Slot untuk Forklift 3 ton

\begin{tabular}{|c|c|c|c|c|c|c|c|c|}
\hline Deskripsi & BlokA & BlokB & BlokC & BlokD & BlokE & BlokF & BlokG B & BlokH \\
\hline $\operatorname{Jarak}(\mathrm{km})$ & 0,75 & 1,09 & 1,81 & 1,48 & 0,75 & 1,08 & 1,48 & 1,71 \\
\hline $\begin{array}{l}\text { Waktu Tempuh (jam); Kee Rata-ratata =4 } \\
\text { kmmjam }\end{array}$ & 0,19 & 0,27 & 0,45 & 0,37 & 0,19 & 0,27 & 0,37 & 0,43 \\
\hline $\begin{array}{l}\text { Konsumsi Solar per Blok (liter) dimana 2,1 } \\
\text { literjam }\end{array}$ & 0,39 & 0,57 & 0,95 & 0,78 & 0,39 & 0,56 & 0,78 & 0,90 \\
\hline Konsumsis Solar per Sot (Liter) & 0,02 & 0,02 & 0,04 & 0,03 & 0,02 & 0,02 & 0,03 & 0,44 \\
\hline Biaza per Slot (RP 9600, per liter) & 157,89 & 228,70 & 380,50 & 325,12 & 157,89 & 215,88 & 310,35 & 374,84 \\
\hline
\end{tabular}

Tabel 11. Biaya Transportasi per Slot untuk Forklift 2,5 ton

\begin{tabular}{|c|c|c|c|c|c|c|c|}
\hline Deskinipsi & Blokd BlokB & BolkC & BiokD & BlokE & BlokF & BlokG & BlokH \\
\hline $\operatorname{Jarak}($ (mm) & $0,7,1,0$ & 1,81 & 1,48 & 0,75 & $1,1,8$ & 1,48 & 1,71 \\
\hline $\begin{array}{l}\text { Waktu Tempuh (jam);Kec Ratar-vata =4 } \\
\text { kmjam }\end{array}$ & $0,19 \quad 0,47$ & 0,45 & 0,37 & 0,19 & 0,27 & 0,37 & 0,43 \\
\hline $\begin{array}{l}\text { Konsumsi Solar per Blok (Iter) dimana? } \\
\text { litererjam }\end{array}$ & $0,38 \quad 0,54$ & 0,91 & 0,74 & 0,38 & 0,54 & 0,74 & 0,86 \\
\hline KonsumsiSolarper Slot(Liter) & $0,02 \quad 0,02$ & 0,04 & $0,0,3$ & 0,02 & 0,02 & $0,0,3$ & 0,04 \\
\hline Biaja per Sol (Rp9600, perl liter) & $150,37,217,81$ & 362,39 & 309,64 & 150,37 & 215,13 & $29 ;, 58$ & 356,99 \\
\hline
\end{tabular}

Data biaya di atas dimasukkan ke tabel transportasi dimana kapasitas kedua forklift masing-masing 95 slot.

\section{Vogel Approximation Method (VAM)}

Metode ini digunakan untuk mendapatkan solusi layak dasar. Matrix VAM dapat dilihat pada tabel 12 berikut ini. 
Tabel 12. Matriks Vogel Approximation Method (VAM)

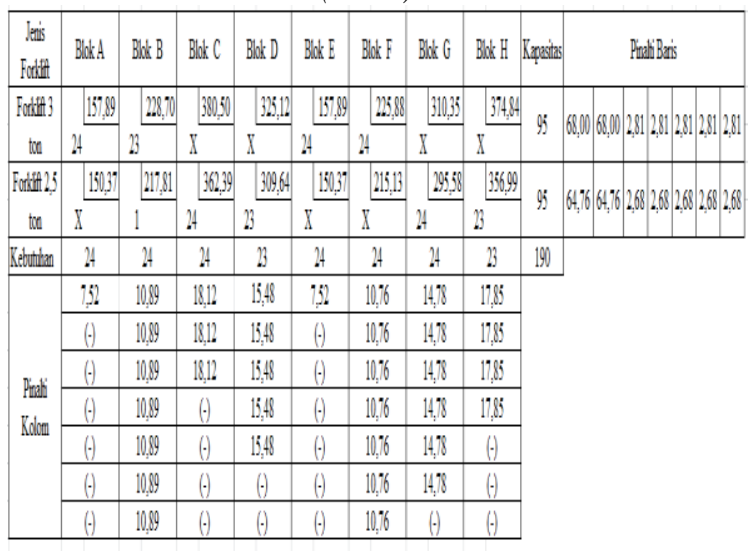

Selisih terbesar diantara pinalti baris dan kolom iterasi 1 adalah angka 68,00 pada baris forklift 3 ton. Alokasikan pada baris forklift 3 ton pada sel yang memiliki biaya terendah (dalam hal ini adalah sel baris forklift 3 ton - kolom blok A). Besarnya alokasi adalah nilai minimum (baris kapasitas forklift 3 ton, kebutuhan blok A) yaitu min $(95,24)$. Jadi alokasinya sebesar 24 slot. Iterasi 2 masih dilakukan karena belum semua kebutuhan terpenuhi. Selanjutnya untuk iterasi 2 kolom blok A tidak dapat diikutsertakan kembali dalam proses perhitungan karena sudah dipenuhi permintaannya. Demikian seterusnya dilakukan sampai iuerasi 7 seperti yang ditunjukkan pada tabel 12 .

\section{MetodeStepping Stone}

Metode ini digunakan untuk mendapatkan solusi optimum dari hasil solusi layak dasar Vogel Approximation Method (VAM). Pada tabel 12 tidak terjadi degenerasi/redundansi, dimana jumlah sel yang terisi adalah 9 sel, sedangkan persyaratan harus terisi 9 sel (jumlah baris + jumlah kolom $-1=2+8-1$ ). Untuk itu variabel epsilon $(\varepsilon)$ tidak dibutuhkan. Selanjutnya pada hasil tabel 12 dilakukan pengujian mengisi sel kosong apakah akan menambah atau mengurangi biaya dengan menggunakan batu loncatan (stepping stone).

$-\mathrm{C} 13=\mathrm{X} 13-\mathrm{X} 23+\mathrm{X} 22-\mathrm{X} 12=$ $(380,50)-(362,39)+(217,81)-(228,70)=$ 7,23
$-\mathrm{C} 14=\mathrm{X} 14-\mathrm{X} 24+\mathrm{X} 22-\mathrm{X} 12=$ $(380,50)-(362,39)+(217,81)-(228,70)=$ 4,59

Demikian selanjutnya dilakukan pengujian untuk sel-sel kosong dan hasilnya menunjukkan seluruhnya bernilai positif. Artinya apabila sel kosong diisi dari sel-sel yang berisi maka hasilnya akan menambah biaya. Jadi hasil pada tabel 12 sudah merupakan hasil optimum dimana alokasi pekerjaan tiap forklift adalah:

- Forklift 3 ton menyimpan dan mengambil barang di blok A (24 slot), blok B (23 slot), blok E (24 slot), blok F (24 slot)

- Forklift 2,5 ton menyimpan dan mengambil barang di blok B (1 slot), blok C (24 slot), blok D (23 slot), blok G (24 slot), blok H (23 slot).

\section{KESIMPULAN}

Berdasarkan hasil analisis dan pembahasan, tata letak gudang PT. Kuda Dua Indonesia yang memberikan perbaikan dengan jarak tempuh yang paling kecil adalah tata letak class based storage. Tata letak ini jika dibandingkan dengan tata letak awal menghasilkan penurunan jarak tempuh sebesar 32,24\%, penurunan luas lantai terpakai untuk penyimpanan sebesar $35,46 \%$, peningkatan kapasitas sebesar $28,57 \%$, peningkatan fleksibilitas sebesar 188,32\%, dan peningkatan produktivitas sebesar $49,98 \%$.

Alokasi pekerjaan optimum yang memberikan biaya transportasi minimum adalah bahwa forklift 3 ton menyimpan dan mengambil barang di blok A (24 slot), blok B (23 slot), blok E (24 slot), blok F (24 slot). Sementara forklift 2,5 ton menyimpan dan mengambil barang di blok B (1 slot), blok C (24 slot), blok D (23 slot), blok G (24 slot), blok H (23 slot).

\section{NOMENKLATUR}

$\mathrm{S}_{\mathrm{j}}=$ kebutuhan penyimpanan untuk produk $\mathrm{j}$

$\mathrm{Tj}=$ kebutuhan throughput atau level

aktivitas untuk produk $\mathrm{j}$

$\mathrm{d}_{\mathrm{ij}}=$ jarak slot $\mathrm{i}$ ke $\mathrm{j}$ (titik $\mathrm{I} / \mathrm{O}$ ) 
$\mathrm{X}_{\mathrm{i}}=$ jarak titik tengah tujuan terhadap sumbu $\mathrm{X}$

$X_{j}=$ titik awal perhitungan $\mathrm{I} / \mathrm{O}$ pada sumbu X (hotizontal)

$\mathrm{Y}_{\mathrm{i}}=$ jarak titik tengah tujuan terhadap sumbu y

$\mathrm{Y}_{\mathrm{j}}=$ titik awal perhitungan $\mathrm{I} / \mathrm{O}$ pada sumbu y (vertical)

\section{DAFTAR PUSTAKA}

Astuti, M., Pratikto, Irawan, Y.S. \& Sugiono, 2016, "Perbaikan Tata Letak Gudang untuk Produk Industri Kreatif Kerajinan Batu Alam dengaan Kebijakan Dedicated Sorage". Seminar Nasional Inovasi dan Aplikasi Teknologi Industri (Seniati) 2016,.C92-C97.

Audrey, O., Sukania W. \& Nasution S.R.. 2019,"Analisis Tata Letak Gudang dengan Menggunakan Dedicated Storage",. Jurnal Asimetrik: Jurnal Ilmiah Rekayasa \& Inovasi.Vol.(1), 43-49.

Basuki \& Kudori M.. 2016, "Implementasi Penempatan dan Penyusunan Barang di Gudang Finished Goods Menggunakan Class Based Storage", Industrial Engineering Journal. Vol. 5(2), 11-16.

Febianti, E., Ilhami M.A. \& Ferdiansah G, 2016,"Relayout Gudang Produk Polypropylene dengan Metode Dedicated Storage". Journal Industrial Servicess. Industrial Engineering Advance Research \& Application, Vol.1(2)

Fumi, A., Scarabotti, L. \& Schiraldi M.M.. 2013, "Minimizing Warehouse Space with a Dedicated Storage Policy", International Journal of Engineering Business Management. Vol. 5(21), 18.

Heragu, S.S. 2016. Facilities Design Fourth Edition. CRC Press, Florida.

Hidayat, M,N. \& Maarif V., 2018, "Perencanaan Tata Letak Gudang Menggunakan Metode Class Based Storag e-Craftpada Distributor Computer \& Office Equipment", Jurnal Evolusi, Vol. 6(2), 36-42.

Johan \& Suhada, K., 2018, "Usulan Perancangan Tata Letak Gudang dengan Menggunakan Metode ClassBased Storage (Studi Kasus di T Heksatex Indah, Cimah Selatan)",. Journal of Integrated System, Vol. $1(1), 52-71 .$.

Meldra, D. \& Purba, H.M.. 2018, "Relayout Tata Letak Gudang Barang dengan Menggunakan Dedicated Storage", Jurnal Rekayasa Sistem Industri, Vol.4(1), 32-39.

Taha, H.A., 2007, Operation Research : An Introduction Eight Edition. Pearson IncPrentice Hall, New Jersey.

Tompkins, White \& Bozer, 2010, Tanchoco. Facilities Planning: Fourth Edition, Wiley, New York

Zaerpour, N.Y. \& de Koster, R.B., 2017, "Optimal Two-Class-Based Storage in a Live-Cube Compact Storage System., IISE Transactions, Vol. 49(7) 653-668.

Zhenyuan, J., Xiaohong, L., Wei. W., Jie, ,D. \& Wang, L, 2011, "Design ad Implementation of Lean Facility Layout System of a Productin Line",. International Journal of Industrial Engineering, Vol.18(5), 260-269. 